\title{
The 11th International Symposium on In Vivo Body Composition Studies
}

\author{
Dympna Gallagher ${ }^{1,2} \cdot$ Bridgette Rizkalla $^{1}$
}

Received: 23 September 2018 / Accepted: 24 September 2018 / Published online: 8 October 2018

(c) Springer Nature Limited 2019

\section{Introduction}

The 11th International Symposium on In Vivo Body Composition Studies was convened at Columbia University Irving Medical Center, New York City on 25 to 27 June 2018. This triennial meeting has as a mission the dissemination of up-to-date information on new and potential future developments in the field of in vivo human body composition research with clinically relevant and translational end-points; the dissemination of research findings arising from recent scientific investigations that demonstrate the importance and utility of measuring body composition for understanding clinically important questions; reporting on recent advances in measurement methods, mathematical modeling and applications; and the encouragement of young investigators to further the objective of training new investigators in the field.

From the first symposium in 1986, there have been a total of 11 symposia over 32 years. There has been no single organization or society specifically dedicated to human body composition methodology development or research and therefore this triennial symposium is the only reoccurring meeting that has assembled leaders in the field. Resulting from these symposia and the proceeding published from these symposia, the scientific community has benefited from the information disseminated. There has been no permanent sponsoring organization involved with these meetings. Each meeting has been organized by a different group of scientific investigators, located where the

Dympna Gallagher

dg108@columbia.edu

1 New York Obesity Research Center, Dept. of Medicine, College of Physicians and Surgeons, Columbia University, New York, USA

2 Institute of Human Nutrition, Columbia University, New York, USA meeting was hosted, who had a fundamental interest in body composition related topics.

\section{Past symposia}

Presented in Table 1 is a listing of all past symposia. The first and second symposia were held at Brookhaven National Laboratory, Brookhaven, New York (1986) and the University of Toronto, Toronto, Canada (1989), both with a focus on the clinical applications of in vivo body composition measurements and available methodologies and techniques. These became common and consistent foci that have spanned the 32 years of the symposia. Combined with the third (Baylor College of Medicine, Baylor, Texas, 1992) and fourth (Lund University, Malmo, Sweden, 1996) symposia, these early symposia emphasized the importance of physics for understanding important questions in clinical medicine and the need to make direct measurements of body components when available, rather than indirect measurements. The use of in vivo neutron activation analysis for elemental measures of nitrogen, calcium, phosphorous, and chlorine for example, were topics that featured strongly among the first four symposia. Physicists from several national laboratories around the globe were among the attendees as they possessed the expertise and their laboratories had the required instrumentation. By the mid 1990s, there was a shift away from methodologies that involved ionizing radiation for nonessential medical purposes. By the fifth symposium (Brookhaven, New York 1989), magnetic resonance imaging (MRI) and magnetic resonance spectroscopy (MRS) were featuring more strongly for the measurement of total body and regional adipose tissue, skeletal muscle, and select organ volumes by MRI and intramyocellular and intrahepatic lipid content by MRS. This shift reflected the advancement of MR acquisition protocols and post-acquisition analysis software, a greater access to MRI for research purposes, and 
Table 1 Historical listing of past International Symposia on In Vivo Body Composition Research (ISBCR)

\begin{tabular}{|c|c|c|}
\hline Year & Location & Theme \\
\hline 11th ISBCR 2018 & $\begin{array}{l}\text { Columbia University Medical Center, New } \\
\text { York, New York, USA }\end{array}$ & $\begin{array}{l}\text { Body composition analysis (Structural, Functional, Kinetic): Technologies } \\
\text { and Models for Biomedical Research and Clinical Applications.D } \\
\text { Gallagher. Proceeding published in the Euro J Clin Nutr (this edition) }\end{array}$ \\
\hline $\begin{array}{l}\text { 10th ISBCR June } \\
11-14,2014\end{array}$ & $\begin{array}{l}\text { University of Lisbon, } \\
\text { Estoril, Portugal }\end{array}$ & $\begin{array}{l}\text { Linking Functional Body Composition to Nutrition, Exercise and Health. } \\
\text { Editors L Bettencourt Sardinha and A Mónica Silva. }\end{array}$ \\
\hline $\begin{array}{l}\text { 9th ISBCR May 21- } \\
24,2011\end{array}$ & $\begin{array}{l}\text { Zhejiang University, } \\
\text { Hangzhou, China }\end{array}$ & $\begin{array}{l}\text { Body Composition: Clinical Implications and Biological Diversity. Editors } \\
\text { S Zhu and Z Wang. Proceedings published in the Int J Obesity. 35, Suppl 2, } \\
\text { May } 2011 .\end{array}$ \\
\hline $\begin{array}{l}\text { 8th ISBCR July 9- } \\
12,2008\end{array}$ & $\begin{array}{l}\text { St. Luke's Hospital \& Columbia University, } \\
\text { New York, New York, USA }\end{array}$ & $\begin{array}{l}\text { Body Composition \& Metabolic Function Across the Lifespan. D } \\
\text { Gallagher \& X Pi-Sunyer. Proceeding published in Int J Body Composition } \\
\text { Studies. 2008; } 3\end{array}$ \\
\hline $\begin{array}{l}\text { 7th ISBCR Sept 7-9, } \\
2005\end{array}$ & $\begin{array}{l}\text { University of Southampton, } \\
\text { England }\end{array}$ & $\begin{array}{l}\text { Linking Structure and Function. M. Elia } \\
\text { Proceeding published in Int J Body Composition Studies. 2005;3:77-132 s. }\end{array}$ \\
\hline $\begin{array}{l}\text { 6th ISBCR Oct 3-5, } \\
2002\end{array}$ & $\begin{array}{l}\text { University of Rome Tor Vergata, } \\
\text { Italy }\end{array}$ & $\begin{array}{l}\text { In Vivo Body Composition Studies. Proceeding published in Acta } \\
\text { Diabetologica, Vol 40, Suppl. 1, Oct 2003. Editors A De Lorenzo, A } \\
\text { Andreoli, and EI Mohamed. Springer-Verlag, Italia, Milano, Italy. }\end{array}$ \\
\hline $\begin{array}{l}\text { 5th ISBCR Oct 7-9, } \\
1999\end{array}$ & $\begin{array}{l}\text { Brookhaven National Laboratories, New } \\
\text { York, New York, USA }\end{array}$ & $\begin{array}{l}\text { Proceeding published in Annals New York Acad Sci. 904, 2000. Editors S } \\
\text { Yasumura, J Wang and RN Pierson Jr. The New York Academy of } \\
\text { Sciences, New York, USA. }\end{array}$ \\
\hline $\begin{array}{l}\text { 4th ISBCR Sept } 18- \\
20,1996\end{array}$ & $\begin{array}{l}\text { Lund University, } \\
\text { Malmo, Sweden }\end{array}$ & $\begin{array}{l}\text { Types, Scope and Applications of Methods Currently Available. } \\
\text { Proceedings published in Appl Radiat Isot. Vol. 49, No 5/6, 1998. Guest } \\
\text { Editors M Alpsten and S Mattsson. Elsevier Science Ltd., UK. }\end{array}$ \\
\hline 3rd ISBCR 1992 & $\begin{array}{l}\text { Baylor College of Medicine, Houston, } \\
\text { Texas, USA }\end{array}$ & $\begin{array}{l}\text { Proceedings published in Basic Life Sciences, vol.60, 1993. Editors KJ } \\
\text { Ellis and Eastman JD. Plenum Publishing Corporation, New York, USA. }\end{array}$ \\
\hline $\begin{array}{l}\text { 2nd ISBCR June } \\
\text { 20-23, } 1989\end{array}$ & $\begin{array}{l}\text { University of Toronto, Toronto, Ontario, } \\
\text { Canada }\end{array}$ & $\begin{array}{l}\text { Clinical Applications and Techniques Employed. Proceedings published in } \\
\text { Basic Life Sciences. Vol 55, } 1989 .\end{array}$ \\
\hline $\begin{array}{l}\text { 1st ISBCR Sept } \\
28 \text { Oct } 1,1986\end{array}$ & $\begin{array}{l}\text { Brookhaven National Laboratories, New } \\
\text { York, New York, USA }\end{array}$ & $\begin{array}{l}\text { In Vivo Body Composition Studies. Proceedings published in The Institute } \\
\text { of Physical Sciences in Medicine 1987. Editors KJ Ellis, S Yasumura and } \\
\text { WD Morgan. Bocardo Press Limited, Oxford, England. }\end{array}$ \\
\hline
\end{tabular}

importantly, the lack of safety issues associated with the MR approach.

Spanning these three decades, the measurement techniques of bioelectrical impedance analysis (BIA) and bioelectrical impedance spectroscopy (BIS), dual-photon absorptiometry (DPA) followed by dual-energy X-ray absorptiometry (DXA) absorptiometry, stable isotopes dilution approach for total body water, and anthropometric methods have featured consistently as commonly used methods. The use of mathematical models and their application in body composition began to feature more prominently by the sixth symposium (University Toro Vega, Rome, Italy: 2002) along with air displacement phlethysmography.

Spanning all three decades, there have been consistent efforts to incorporate body composition to improve the clinical diagnosis, treatment effects and outcomes. A greater focus on in vivo measurements during pregnancy and early life became evident from the seventh symposium (University of Southampton, Southampton, UK: 2005). All subsequent symposia placed a greater emphasis on linking body composition to function: metabolic function at the eighth symposium (St. Luke's Hospital/Columbia
University, New York: 2008), biological diversity at the ninth symposium (Zhejiang University, Hangzhou, China: 2011), linking functional body composition to nutrition, exercise and health, at the tenth symposium (University of Lisbon, Estoril, Portugal; 2014), and a composite of these at this most recent and eleventh symposium.

\section{The 11th symposium}

The two and one-half day program included 19 invited speaker lectures, 29 oral presentations, and 30 poster presentations. There were five poster sessions and each session consisted of six presenters and was led by one of three experts (Drs. Bosy-Westphal, Heymsfield, or Muller). International attendees represented Australia, Austria, Brazil, China, Denmark, Germany, Ireland, Italy, Israel, Japan, Korea, Mexico, Norway, Portugal, New Zealand, Russia, South Africa, Spain, Sweden, United Kingdom, and Uruguay. Eleven of the invited speaker contributed manuscripts from their lectures for publication in this volume. From among the invited speaker lectures that do not appear for publication here, a noteworthy topic that appeared for the 
first time was a lecture focused on the molecular physiology relating the FTO locus to effects on body weight (Rudolph Leibel, MD, Columbia University, New York). This intronic (non-coding) region of the FTO gene conveys a statistically very strong, quantitatively modest effect on human body weight, primarily by effects on energy intake. The possible role of transcription factor binding sites in this region, specifically affect the expression of a primary cilium gene, RPGRIP1L, was described in detail.

The next and 12th International Symposium on In Vivo Body Composition Studies is being planned for 2021 and the host site is likely to be The University of Auckland, New Zealand.
Acknowledgements We extend our appreciation to Laura Yasso (Program Manager) and staff in Continuing Medical Education, Physicians \& Surgeons and our thanks for support received through Educational Grants from Mead Johnson \& Company, LLC and Weight Watchers. The commercial exhibitors (in alphabetical order) were AMRA Medical, Bodystat, COSMED, EchoMRI, InBody USA, and Tanita Corporation.

\section{Compliance with ethical standards}

Conflict of interest The authors declare that they have no conflict of interest. 